Pflügers Arch. 302, 192 (1968)

\title{
Erratum
}

\section{Voltage Clamp Experiments on Frog Atrial Heart Muscle Fibres with the Sucrose Gap Technique}

\author{
O. RougIER, G. VASsoRT, and R. StäMPFLI
}

Pflügers Archiv 301, 91-108 (1968)

Page 93, $7^{\text {th }}$ line from the bottom: for $100 \Omega, \operatorname{read} K \Omega$.

Fig. 6 on page 99 is upside down.

Bibliography: Title of the work by RodGTER, O., et al., 1968:

Analyse qualitative en voltage imposé $d u$ courant de membrane de la fibre musculaire squelettique.

Guy Vassort's adress is not Laboratoire de Physiologie Companie, but Laboratoire des Physiologie Comparée. Please correct on page 108. 